\title{
The role of selenium in the treatment of Hashimoto's disease
}

\section{Znaczenie selenu w leczeniu choroby Hashimoto}

\author{
Faculty of Medicine, Ludwik Rydygier Collegium Medicum in Bydgoszzz, Nicolaus Copernicus University in Toruń, Bydgoszzz, Poland \\ Correspondence: Katarzyna Banaszzzyk, Marii Skłodowskiej-Curie 9, 85-001 Bydgoszzz, Poland, tel.: + 48794053 852, e-mail: kbanaszczyk570@gmail.com
}

\begin{abstract}
Selenium is important for the proper functioning of the human body. This element is closely related to the proper functioning of the thyroid gland and normal metabolism of thyroid hormones. Moreover, it plays a role in the treatment of diseases affecting this organ. The present work was aimed at collecting recent reports on the effect of selenium supplementation on the course of Hashimoto's disease and was an attempt to explain how this element can affect the thyroid gland. The paper presents the effect of selenium supplementation at various stages of Hashimoto's disease and the possible molecular basis for the observed biochemical and therapeutic changes. The studies presented by the authors describe the effect of selenium on, inter alia, the level of antithyroid antibodies, proinflammatory factors and echogenicity of the thyroid in people with Hashimoto's disease. The article also discusses interesting molecular studies describing the importance of selenium in the process of apoptosis, or in the modification of the HLA expression on thyroid cells. Selenium is probably involved in the modification of autoimmune reactions in the affected thyroid gland. What is more, thanks to its special antioxidant properties, selenium reduces chronic inflammation in the thyroid with Hashimoto's disease. It is definitely worth paying attention to this micronutrient because it may improve the therapy of chronic autoimmune thyroiditis and, maybe in some time, after more clinical investigation, it will become an important part of the therapy in this disease entity.
\end{abstract}

Keywords: selenium, Hashimoto's disease, treatment of Hashimoto's disease

Selen ma duże znaczenie dla prawidłowego funkcjonowania organizmu człowieka. Pierwiastek ten jest ściśle związany z prawidłowym funkcjonowaniem tarczycy oraz prawidłowym metabolizmem hormonów tarczycowych, pełni również rolę w leczeniu chorób tego narządu. Celem niniejszego opracowania było zebranie ostatnich doniesień na temat wpływu suplementacji selenu na przebieg choroby Hashimoto. Stanowi ono pewnego rodzaju próbę wyjaśnienia sposobu, w jaki pierwiastek ten może oddziaływać na gruczoł tarczowy. W pracy przedstawiono wpływ suplementacji selenu w różnych stadiach choroby Hashimoto oraz możliwe molekularne podstawy obserwowanych zmian biochemicznych i terapeutycznych. Zaprezentowane przez autorów badania opisują wpływ selenu m.in. na stężenia przeciwciał przeciwtarczycowych i czynników prozapalnych oraz echogeniczność tarczycy u osób z chorobą Hashimoto. W artykule zreferowano także interesujące badania molekularne opisujące istotne znaczenie selenu w procesie apoptozy czy w modyfikacji ekspresji cząsteczek układu HLA tyreocytów. Selen prawdopodobnie jest zaangażowany w reakcje autoimmunologiczne przebiegające w dotkniętym chorobą narządzie tarczowym. Co więcej, dzięki swoim szczególnym właściwościom antyoksydacyjnym ogranicza przewlekły stan zapalny w tarczycy, który towarzyszy chorobie Hashimoto. Zdecydowanie warto poświęcić uwagę temu mikroelementowi, ponieważ być może usprawni on terapię przewlekłego autoimmunologicznego zapalenia tarczycy i za jakiś czas, po kolejnych badaniach klinicznych, stanie się ważnym elementem terapii tej jednostki chorobowej.

Słowa kluczowe: selen, choroba Hashimoto, leczenie choroby Hashimoto 


\section{INTRODUCTION}

$\mathrm{H}$ ashimoto's disease, also known as chronic autoimmune thyroiditis, is the most common autoimmune disease and also the most common cause of hypothyroidism in areas with proper iodine intake $^{(1)}$. The classical course of the disease with goitre was described for the first time in 1912 by Japanese surgeon Hakaru Hashimoto. In his work, he presented four patients with thyroid dysfunctions, which he called lymphatic struma $^{(2)}$. The annual incidence of Hashimoto's disease in the world is around 0.3-1.5 cases per 1,000 people ${ }^{(3)}$. Although more than a century has passed since the discovery of this disease, its etiopathogenesis has not been fully elucidated. The occurrence of Hashimoto's disease is associated with genetic and environmental factors. Of the dietary factors, insufficient selenium intake may be of significance. In a Chinese cross-sectional study, conducted in two districts of the Shaanxi province, it was demonstrated that Hashimoto's disease and other thyroid abnormalities (hypothyroidism, subclinical hypothyroidism, enlarged gland) were significantly more frequent in the area where the selenium content in the environment was reduced than in the area where the level of selenium was normal. The reduced level of selenium in the environment corresponded to a 2 -fold lower serum level of this element in people living in these areas in comparison with people living in areas with the correct selenium content ${ }^{(4)}$. Although selenium deficiency is not currently considered a risk factor for the development of Hashimoto's disease, and its supplementation is not an effective way to treat it, more and more studies focus on the effect of this element on the course of the disease and its etiopathogenesis. The aim of this study was to systematise the current reports on the effect of selenium supplementation on the course of Hashimoto's disease.

\section{SHORT CHARACTERISTICS OF HASHIMOTO'S DISEASE}

Hashimoto's disease is associated with the occurrence of antithyroid antibodies: against thyroid peroxidase (anti-TPO) and against thyroglobulin (anti-TG); sometimes, there are also antibodies blocking the thyroid-stimulating hormone (TSH) receptor ${ }^{(5)}$. The developing infiltrates in the thyroid are composed of mononuclear cells, with predominating lymphocytes that can organise into lymphoid nodules, as well as macrophages and plasma cells ${ }^{(6)}$. The immunological phenomena are Th1-dependent, and the most important role is played by cytotoxic $\mathrm{T}$ cells whose activity leads to the destruction of thyroid follicular cells. Moreover, regulatory functions of $\mathrm{T}$ cells are disturbed. The secretion of proinflammatory cytokines is increased, while the secretion of anti-inflammatory cytokines is reduced. Due to the disturbance of this balance, apoptosis of thyroid epithelial cells is enhanced ${ }^{(5,6)}$. Chronic inflammation of the gland leads to
The disease may be asymptomatic for a long time. The onset may be associated with transient hyperfunction of the gland (hashitoxicosis) due to increased destruction of the thyroid parenchyma and release of hormones into the blood. Then, there is a short period of euthyroidism that changes into permanent hypothyroidism, which may be subclinical at the beginning ${ }^{(5,7)}$. The disease develops slowly, with clinical symptoms typical of hypothyroidism developing over time. Due to the multidirectional action of thyroid hormones, these symptoms vary and concern many body systems ${ }^{(6)}$. The diagnosis of the disease is based on the presence of antithyroid antibodies in the blood and the determination of TSH and fT4 concentrations. TSH levels are elevated, while fT4 levels depend on the phase of the disease. In the transient phase of hyperthyroidism, the level of fT4 may be increased, but it remains normal in the phase of subclinical hypothyroidism and euthyroidism. The diagnosis of Hashimoto's disease is based on the finding of increased anti-TPO antibody levels in people with goitre, reduced (atrophic) thyroid or hypothyroidism. Anti-TG antibodies are less important in the diagnosis, because they are less specific than anti-TPO antibodies ${ }^{(5)}$. Ultrasound examination (US) is also helpful. The thyroid gland in Hashimoto's disease is characterised by reduced echogenicity; the structure of the gland may be irregular and nodular ${ }^{(6)}$.

Typically, the treatment is based on hormone substitution, involving L-thyroxine administration in overt hypothyroidism $^{(5)}$.

\section{SELENIUM IN THE HUMAN BODY}

Selenium was discovered in 1817 by Swedish chemist Jöns Berzelius and was considered to be a toxic element until 1957 when its positive effect on reducing liver necrosis in rats was noticed. From the chemical point of view, selenium is a non-metal. As an inorganic compound, it assumes the form of selenates (IV), and in the organic form, it creates amino acids: selenomethionine and selenocysteine. In these amino acids, the sulphur atom is replaced with a selenium atom $^{(8)}$. Selenium is important for the proper functioning of the human body, because, in the form of selenocysteine, it is a part of many enzymes important for metabolism. To date, 25 selenoenzymes and selenoproteins have been identified. These are, for example, isoforms of glutathione peroxidase, iodothyronine deiodinase and thioredoxin reductase. In these enzymes, selenium acts as an active centre. Thanks to this, it participates in oxidation and reduction reactions, scavenging free oxygen radicals and protecting cell membranes against oxidative stress. Being a component of iodothyronine deiodinases, selenium has an effect on the metabolism of thyroid hormones. Thioredoxin reductases act as apoptosis inhibitors, which may indicate that selenium plays some role in this process. The influence of selenium on the immune system has also been examined, and it has been shown that its supplementation causes an increased NK (natural killers) reaction to an exogenous 
antigen, increased $\mathrm{T}$ cell activity and their conversion into cytotoxic lymphocytes ${ }^{(8,9)}$. Moreover, selenium also has antibacterial and antiviral properties. It can probably inhibit the conversion of human immunodeficiency virus (HIV) infection to full-blown acquired immunodeficiency syndrome (AIDS) and progression of viral hepatitis. There are also reports on the antitumor effects of this element and its positive effect on the prevention of diabetes and cardiovascular diseases ${ }^{(10)}$.

Selenium deficiency is identified primarily in areas where the content of this element in the soil is low (China, Siberia) ${ }^{(10)}$. Epidemiological research indicates that selenium deficiency may concern as many as 1 billion people worldwide ${ }^{(11)}$. The main sources of selenium in food are meat, fish, pasta and oatmeal. Brazil nuts contain the greatest amount of this element ${ }^{(8)}$. The body's requirement for selenium, which preconditions proper activity of selenoproteins, varies from $60 \mu \mathrm{g}$ to $75 \mu \mathrm{g}$ daily ${ }^{(12)}$.

In comparison to other organs, the thyroid is characterised by a high content of selenium, even in conditions of selenium deficiency in the body. As a component of certain selenoproteins, this element is involved in the protection of thyroidocytes against harmful effects of oxygen free radicals. As has already been mentioned, selenium is part of three isoforms of iodothyronine deiodinases. Type 1 and 2 of this enzyme are responsible for thyroxin (T4) de-iodination to its more active form, triiodothyronine (T3). Type 3 deiodinase breaks down T4 and T3 into inactive forms, which is important for protecting the foetus from the excess of maternal hormones ${ }^{(13)}$. Research suggests that, in diseases with elevated levels of free oxygen radicals, such as hydrogen peroxide, selenium supplementation has a positive effect on the thyroid gland by reducing inflammation. This happens thanks to the increased activity of antioxidant enzymes containing selenium ${ }^{(14)}$. It cannot be denied that selenium is a closely related element to the proper function of the thyroid gland and the proper metabolism of thyroid hormones.

\section{SELENIUM IN THE TREATMENT OF HASHIMOTO'S DISEASE}

In recent years, many studies have addressed the importance of selenium in the treatment of Hashimoto's disease. One of the latest randomised trials was carried out by a team of Chinese researchers and compared treatment of chronic lymphocytic thyroiditis with levothyroxine monotherapy with the therapy in which levothyroxine was used in combination with selenium. The research was conducted on 60 patients who were tested for selenium, anti-TPO, anti-TG and inflammatory cytokines before and after treatment. The first study group $(n=24)$ received levothyroxine alone for 3 months, and the second group $(n=36)$ received levothyroxine and a selenium preparation. In the levothyroxine plus selenium group, a significant increase in the selenium level was observed, which correlated with a decrease in anti-TPO and anti-TG antibodies as well as proinflammatory interleukin 2. However, there was no difference in the level of interleukin 10 between both groups ${ }^{(15)}$. The presented study indicates that selenium in combination with levothyroxine has a beneficial therapeutic effect in patients with Hashimoto's overt hypothyroidism. This may be related to the modulating effect of selenium on the immune system and a reduction of inflammation as a result of a decrease in the proinflammatory interleukin 2 level.

Another recent study, conducted by Italian researchers, was a prospective, randomised trial aimed to determine the effect of selenium supplementation in patients with autoimmune thyroiditis at the stage of benign, subclinical hypothyroidism with TSH $<10 \mathrm{mU} / \mathrm{L}$. The study included 196 patients who were divided into those receiving $83 \mu \mathrm{g}$ of selenomethionine daily $(n=98)$ and controls that did not receive selenomethionine $(n=98)$. One hundred and ninety-two patients completed the study. After 4 months of treatment and follow-up examinations, euthyroidism was observed in $17.2 \%$ of the patients treated with selenomethionine $(n=33)^{(16)}$. The above study indicates a positive response to selenium supplementation in the subclinical stage of hypothyroidism in the course of Hashimoto's disease.

While the studies quoted above clearly indicate a positive therapeutic effect of selenium supplementation in patients with autoimmune hypothyroidism treated with levothyroxine in combination with selenium supplementation and in patients with subclinical hypothyroidism, the question arises about a possible effect of this supplementation in the stage of euthyroidism, in patients who are not treated with levothyroxine but who exhibit a clinically significant anti-TPO antibody level $(\geq 100 \mathrm{kU} / \mathrm{L})$. This is a group of patients at risk for subclinical or even overt clinical autoimmune hypothyroidism. Finding the answer to this question was the aim of a study conducted by researchers from the University of Amsterdam. In their randomised, double-blind study, some patients $(n=30)$ received daily selenium supplementation ( $200 \mu \mathrm{g}$ sodium selenite), while the remaining patients $(n=31)$ received placebo for the period of 6 months. At baseline and after 3, 6 and 9 months from the beginning of the study, the levels of TSH, fT4, selenium and selenoprotein $\mathrm{P}$ were determined, and also an additional quality of life indicator was measured. Despite a small sample size, the results proved to be extremely interesting. The only difference between the selenium group and the placebo group was higher selenium and selenoprotein $\mathrm{P}$ levels in the former group. However, the study did not show any significant differences in the levels of anti-TPO antibodies and TSH, or in the quality of life $\mathrm{e}^{(17)}$.

Another study that evaluated the effect of selenium supplementation in euthyroid patients is the Esposito et al. study. It was based on 76 patients with euthyroidism, not treated with levothyroxine, who were divided into the study group $(n=38)$ receiving $166 \mu \mathrm{g}$ L-selenomethionine daily and the control group $(n=38)$ receiving placebo. At 0 , 3 and 6 months, the patients were tested for TSH, fT4, fT3 
and anti-TPO antibodies, and had a thyroid US performed. The levels of TSH, fT4, fT3, anti-TPO antibodies and thyroid echogenicity did not differ in a statistically significant way between the study and control groups at 0,3 and 6 months. In the selenomethionine group, the fT4 value decreased after 3 months, and the fT 3 value increased. In contrast, the controls showed a decrease in $\mathrm{fT} 3$ compared to the baseline value ${ }^{(18)}$. The two studies mentioned above indicate that selenium supplementation has a limited effect on the course of Hashimoto's disease in the stage of euthyroidism. An extremely interesting study, not only because of the results it yielded, but also because of its distinguishing methodology, which stood out from other cited studies, was a prospective study of the authors from the University of Padua. It aimed to assess the effect of selenium supplementation in doses near the daily requirement on the natural course of autoimmune thyroiditis. This design was different from the previously cited studies assessing the impact of high doses, several times higher than the daily requirement. The study included 76 patients with normal thyroid function or subclinical hypothyroidism, in the initial stage of the disease with normal or slightly elevated TSH levels and fT4 levels within the normal range. The patients were not treated with levothyroxine. After randomised assignment, two groups were formed: group $1(n=46)$ receiving a dose of selenium matching the daily requirement $(80 \mu \mathrm{g})$ for 12 months daily, and group $0(n=30)$, not receiving selenium preparations or any other supplements with a trace amount of this element. At baseline, 6 months and 12 months, the authors assessed the levels of anti-TPO and anti-TG antibodies, TSH and fT4 as well as echogenicity of the thyroid gland in a high-resolution ultrasound. Interestingly, this was the first study in which a quantitative method was used during ultrasound image processing (a pixel grey scale covering the range from $0=$ white to 255 = black), enabling objective assessment of changes in the thyroid. The results turned out to be extremely interesting. The echogenicity of the thyroid gland decreased significantly in both groups of patients at 6 months, but at 12 months there was no progression of changes on US in the selenium group, while the echogenicity decreased further in the patients that did not receive this element. Laboratory tests also provided interesting data. At 6 months, there were no significant differences in the level of antibodies between group 0 and group 1 . However, at 12 months, a significant decrease in antibody levels was observed in the selenium group, in contrast to the group that did not receive any supplementation. Interestingly, 5 patients turned out to be anti-TPO-negative. The lack of significant changes in the levels of TSH and fT4 in both groups is another interesting finding. This way, the researchers proved that selenium doses near the daily requirement may affect the natural course of autoimmune thyroiditis, both in terms of reducing antibody levels and preventing the reduction of thyroid echogenicity ${ }^{(19)}$. This last aspect seems to be exceptionally interesting, because, as was already demonstrated at the turn of the century, low echogenicity of the thyroid parenchyma is associated with inflammatory infiltration within it and high antibody titre as well as correlates with thyroid function deterioration in the group of patients with autoimmune inflammation ${ }^{(20,21)}$. This may indirectly indicate that taking daily physiological doses of selenium could improve the structure of the thyroid parenchyma.

In 2012, a group of Chinese scientists published a study, which shed some more light on the nature of changes in anti-TPO antibody levels with concurrent selenium supplementation. The aim of the study was not only to describe changes in total antibody titres, but also to investigate the nature of changes in the level of individual subclasses of the said immunoglobulins. A group of 134 patients with autoimmune thyroiditis was divided first of all into a group of patients with euthyroidism or subclinical hypothyroidism $(n=89)$ and into the group of patients with clinically overt hypothyroidism $(n=45)$. Subsequently, the patients from each of these groups were further randomly assigned to subgroups (49/89 and 28/45) receiving selenium supplementation $(200 \mu \mathrm{g})$ every day for 6 months or receiving placebo. The total level of anti-TPO antibodies, their individual subclasses, TSH, fT4 and selenium were determined at baseline, at 3 months and at 6 months. A decrease in the total antibody level was demonstrated in the selenium groups, with the decrease being greater in the patients initially assigned to the group with overt clinical hypothyroidism. At the same time, the dominant subclasses of anti-TPO antibodies were IgG1 (72\%), IgG3 (41\%) and IgG4 (72\%), with the percentage and titre of the IgG3 being higher among patients with overt hypothyroidism. When evaluating the changes in the level of individual subclasses, it was demonstrated that the drop of the total anti-TPO antibody titre, observed in patients receiving selenium supplementation, was predominated by a decrease in IgG1 and IgG3 subclasses $^{(22)}$.

The question about a possible mechanism by which selenium supplementation could contribute to improving the clinical status of patients with autoimmune thyroid diseases was also addressed by Hungarian authors. They also showed a beneficial effect of adding selenium supplementation to levothyroxine therapy in patients with autoimmune thyroid diseases. This effect included a decrease in the level of antibodies, mainly anti-TPO. This time, the authors investigated the influence of selenium $(10,50$ and $100 \mathrm{nmol} / \mathrm{mL}$ of sodium selenite) on the expression of HLA molecules in in vitro cultures of human thyrocytes. HLA-DR expression was induced by adding interferon $\gamma$ (IFN- $\gamma)$ to the culture, and fluorescence-activated cell sorting (FACS) was used to determine HLA-positive thyroidocytes. It has been shown that the presence of selenium in the culture inhibits HLA-DR expression, with the effect being dependent on the selenium concentration. At the same time, there were no significant differences in HLA-DR expression depending on whether selenium was added to the culture before or after thyrocyte exposure to IFN- $\gamma$. Subsequently, a possible relationship 
between HLA-DR expression on thyroid cells and the role of selenium as an antioxidant was examined, showing an inversely proportional relationship between HLA-DR expression and the total antioxidant capacity of individual selenium doses ${ }^{(23)}$. The quoted results turned out to be extremely interesting in the context of a possible modifying effect of selenium supplementation on the course of the disease process, because individual HLA haplotypes are likely to contribute to the pathogenesis of autoimmune thyroid diseases $^{(24,25)}$.

In another study, a group of Italian authors also tried to find out how selenium supplementation can affect the decrease in antibody titres demonstrated in previous analyses. The experiment utilised rat thyroid follicular cells (FRTL5). The cells, previously incubated under appropriate conditions and exposed to various concentrations of selenium chloride, were tested for the effect of these concentrations on the apoptosis process. It was shown that selenium chloride decreases transcription and expression of proapoptotic protein genes ( $\mathrm{p} 53, \mathrm{Bim})$ and increases expression of antiapoptotic protein genes (NF- $\kappa \mathrm{B}, \mathrm{Bcl}-2)$. Selenium supplementation increased the survival rate of rat thyroid cells and stimulated their growth and proliferation. It also inhibited apoptosis via the FAS-dependent pathway. These studies indicate that selenium has a modulating effect on apoptosis occurring in thyroid follicular cells. The protective effect of selenium on thyroid cells has been demonstrated, which may be related to the already demonstrated decrease in thyroid antibody levels and improvement of the US thyroid status in patients with autoimmune thyroid diseases ${ }^{(26)}$. Research on selenium supplementation continues. A Danish randomised, multicentre CATALYST trial revealed interesting observations. The study included 472 patients over 18 years of age, suffering from chronic thyroiditis and taking levothyroxine preparations. The patients' serum anty-TPO antibody levels of $>100 \mathrm{IU} / \mathrm{mL}$ persisted for one year. A half of the patients additionally received $200 \mu \mathrm{g}$ daily of yeast enriched with selenium, while the control group received placebo. After the experiment, the authors linked the correlation between selenium supplementation and the dose of thyroxine in the selenium group, and attempted to predict a reduction in the dose of thyroxine needed to obtain the same therapeutic effect. Other aspects of this study were the confirmation of the difference in the levels of anti-TPO antibodies between the selenium supplementation group and the control group, and the assessment with a quality of life questionnaire during the 12-month study ${ }^{(27)}$.

\section{CONCLUSIONS}

Selenium is a microelement that, as recent research indicates, is involved not only in the regulation of various physiological processes in the human body, but also in the therapy of pathophysiological conditions. The authors of this work tried to present the role of this element in the treatment of Hashimoto's disease. Based on the quoted sources, it can be assumed that selenium has a significant role in the treatment of this type of thyroiditis. The main mechanism of action is most likely the regulation of the autoimmune process that underlies this disease entity. This is expressed in the ability of the said element to reduce the autoantibody titre, which has been proven in numerous studies. At the same time, many issues still remain unclear, and further experience does bring answers, but also produces further questions. This shows the need for further research on the importance of selenium, including its role in the treatment of Hashimoto's disease. Perhaps in the future, this microelement will permanently enter the therapeutic programme.

\section{Conflict of interest}

Authors do not declare any financial or personal relations with other people or organisations which may negatively influence the content of this publication or claim the right to this publication.

\section{References}

1. Chaker L, Bianco AC, Jonklaas J et al.: Hypothyroidism. Lancet 2017; 390: 1550-1562.

2. Caturegli P, De Remigis A, Chuang K et al.: Hashimoto's thyroiditis: celebrating the centennial through the lens of the Johns Hopkins hospital surgical pathology records. Thyroid 2013; 23: 142-150.

3. Latina A, Gullo D, Trimarchi F et al.: Hashimoto's thyroiditis: similar and dissimilar characteristics in neighboring areas. Possible implications for the epidemiology of thyroid cancer. PLoS One 2013; 8: e55450.

4. Wu Q, Rayman MP, Lv H et al.: Low population selenium status is associated with increased prevalence of thyroid disease. J Clin Endocrinol Metab 2015; 100: 4037-4047.

5. Jarząb B, Lewiński A, Płaczkiewicz-Jankowska E: Choroby tarczycy. In: Gajewski P (ed.): Interna Szczeklika. Medycyna Praktyczna, Kraków 2016: 1256.

6. Caturegli P, De Remigis A, Rose NR: Hashimoto thyroiditis: clinical and diagnostic criteria. Autoimmun Rev 2014; 13: 391-397.

7. Przybylik-Mazurek E, Hubalewska-Dydejczyk A, Huszno B: Niedoczynność tarczycy na tle autoimmunologicznym. Alergologia, Immunologia 2007; 4: 64-69.

8. Klecha B, Bukowska B: Selen w organizmie człowieka - charakterystyka pierwiastka i potencjalne zastosowanie terapeutyczne. Bromat Chem Toksykol 2016; 49: 818-829.

9. Ratajczak M, Gietka-Czernel M: Rola selenu w organizmie człowieka. Post N Med 2016; 29: 929-933.

10. Stuss M, Michalska-Kasiczak M, Sewerynek E: The role of selenium in thyroid gland pathophysiology. Endokrynol Pol 2017; 68: $440-465$.

11. Holben DH, Smith AM: The diverse role of selenium within selenoproteins: a review. J Am Diet Assoc 1999; 99: 836-843.

12. Lacka K, Szeliga A: Significance of selenium in thyroid physiology and pathology. Pol Merkur Lekarski 2015; 38: 348-353.

13. Köhrle J, Jakob F, Contempré B et al.: Selenium, the thyroid, and the endocrine system. Endocr Rev 2005; 26: 944-984.

14. Negro R: Selenium and thyroid autoimmunity. Biologics 2008; 2 : 265-273.

15. Yu L, Zhou L, Xu E et al.: Levothyroxine monotherapy versus levothyroxine and selenium combination therapy in chronic lymphocytic thyroiditis. J Endocrinol Invest 2017; 40: 1243-1250.

16. Pirola I, Gandossi E, Agosti B et al.: Selenium supplementation could restore euthyroidism in subclinical hypothyroid patients with autoimmune thyroiditis. Endokrynol Pol 2016; 67: 567-571. 
17. Eskes SA, Endert E, Fliers E et al.: Selenite supplementation in euthyroid subjects with thyroid peroxidase antibodies. Clin Endocrinol (Oxf) 2014; 80: 444-451.

18. Esposito D, Rotondi M, Accardo G et al.: Influence of short-term selenium supplementation on the natural course of Hashimoto's thyroiditis: clinical results of a blinded placebo-controlled randomized prospective trial. J Endocrinol Invest 2017; 40: 83-89.

19. Nacamulli D, Mian C, Petricca D et al.: Influence of physiological dietary selenium supplementation on the natural course of autoimmune thyroiditis. Clin Endocrinol (Oxf) 2010; 73: 535-539.

20. Marcocci C, Vitti P, Cetani F et al.: Thyroid ultrasonography helps to identify patients with diffuse lymphocytic thyroiditis who are prone to develop hypothyroidism. J Clin Endocrinol Metab 1991; 72: 209-213.

21. Huber G, Staub JJ, Meier C et al.: Prospective study of the spontaneous course of subclinical hypothyroidism: prognostic value of thyrotropin, thyroid reserve, and thyroid antibodies. J Clin Endocrinol Metab 2002; 87: 3221-3226.
22. Zhu L, Bai X, Teng WP et al.: [Effects of selenium supplementation on antibodies of autoimmune thyroiditis]. Zhonghua Yi Xue Za Zhi 2012; 92: 2256-2260.

23. Balázs C, Kaczur V: Effect of selenium on HLA-DR expression of thyrocytes. Autoimmune Dis 2012; 2012: 374635.

24. Zaletel K, Gaberšček S: Hashimoto's thyroiditis: from genes to the disease. Curr Genomics 2011; 12: 576-588.

25. Jacobson EM, Huber A, Tomer Y: The HLA gene complex in thyroid autoimmunity: from epidemiology to etiology. J Autoimmun 2008; 30: 58-62.

26. Nettore IC, De Nisco E, Desiderio $S$ et al.: Selenium supplementation modulates apoptotic processes in thyroid follicular cells. Biofactors 2017; 43: 415-423.

27. Winther $\mathrm{KH}$, Watt $\mathrm{T}$, Bjørner JB et al.: The chronic autoimmune thyroiditis quality of life selenium trial (CATALYST): study protocol for a randomized controlled trial. Trials 2014; 15: 115. 